\title{
Effect of surface disinfectants on fruit blemishes (Sooty blotch \& Flyspeck) and quality of apple (Malus domestica Borkh.) cv. Banky during cold storage
}

\author{
Kiran Fareed, Muhammad Jamil Ahmed, Mehdi Maqbool*, Noosheen \\ Zahid, Abdul Hamid and Syed Zulfiqar Ali Shah \\ Department of Horticulture, Faculty of Agriculture, University of the Poonch, Rawalakot, Azad Jammu \& Kashmir- \\ Pakistan \\ *Corresponding author's email: mehdimaqbool@upr.edu.pk
}

Citation

Kiran Fareed, Muhammad Jamil Ahmed, Mehdi Maqbool, Noosheen Zahid, Abdul Hamid and Syed Zulfiqar Ali Shah. Effect of surface disinfectants on fruit blemishes (Sooty blotch \& Flyspeck) and quality of apple (Malus domestica Borkh.) cv. Banky during cold storage. Pure and Applied Biology. Vol. 8, Issue 1, pp1126-1134. http://dx.doi.org/10.19045/bspab.2019.80054

\begin{tabular}{llll}
\hline \hline Received: 12/12/2018 & Revised: 19/03/2019 & Accepted: 28/03/2019 & Online First: 06/04/2019 \\
\hline \hline
\end{tabular}

\section{Abstract}

Different surface disinfectants were used to control the fruit blemishes caused by sooty blotch (SB) and flyspeck (FS). Treatments included sodium hypochlorite (200, 500 and $800 \mathrm{ppm})$, copper sulphate $(100,200$ and $300 \mathrm{ppm})$, hydrogen peroxide $(100,360$ and $480 \mathrm{ppm})$ and potassium bicarbonate $(200,500$ and $800 \mathrm{ppm})$ were used to maximize the storage life of apple fruits. Apple fruits after application of treatments were stored at $2^{\circ} \mathrm{C}$ and $80-85 \% \mathrm{RH}$ for 90 days. The highest control of fruit blemishes was observed with $800 \mathrm{ppm}$ sodium hypochlorite which was nonsignificantly $(P>0.05)$ different with $500 \mathrm{ppm}$ sodium hypochlorite after 90 days of storage. Weight loss was less in fruits treated with $500 \mathrm{ppm}$ sodium hypochlorite (30\%) as compared to control fruits (85\%). Further, apple fruits treated with $500 \mathrm{ppm}$ sodium hypochlorite showed the best results in terms of total soluble solids, titratable acidity, sugars and sensory evaluation as well. Fruits treated with other surface disinfectants also showed good results but not as effective as 500 ppm sodium hypochlorite treatment did. Thus, it could be concluded from present study that 500 ppm sodium hypochlorite treatment have the potential to be used in controlling apple fruit blemishes and maintain fruit quality up to 90 days.

Keywords: Apple; Fruit blemishes; Physical quality; Sensory evaluation

\section{Introduction}

Apple (Malus dmoestica Borkh.) is one of the most widely grown fruit of Pakistan. It is ranked $5^{\text {th }}$ in terms of production and $11^{\text {th }}$ in export, therefore contributing significantly in national economy [1]. Plant diseases significantly damage growth and development of plants, leading to reduction in yield and quality of produce [2-4]. Since last few years, apple fruits are facing serious problem of sooty blotch (SB) and flyspeck (FS) in Azad Jammu and Kashmir [5]. A complex fungal disease i.e., SB and FS is caused by different epiphytic fungal species 
of Ascomycota [6]. This fungal complex grows on the upper cuticle layer of apple fruit [7-9]. A fungus colonizes the fruit surface with no penetration inside the cuticle [10]. In case of SB, infected fruit signs a dark smudge like blemish on the surface of the fruit. However, in case of FS fecal spots resembling attack of insects appears on the fruit [11]. Presence of either SB or FS on fruits lowers the market value and shelf life of fruits. This complex fungus is often controlled by the sprays of chemical fungicides. Severity and incidents of both SB and FS vary at spatiotemporal scale and also influenced by management practices [12]. However, in higher mountain regions of Pakistan such as Azad Jammu and Kashmir, high rainfall and relative humidity provides a suitable growing environment for SB and FS disease complex $[13,14]$. Even with the use of fungicides almost all the apples produced in this area are affected by SB and FS [15]. Apple fruits obtained from the fungicide sprayed trees often contain residues of these chemicals [16]. Since 1996, according to the Fruit Quality Protections Act (FQPA), growers lost the broad spectrum fungicides which were effective against SB and FS [17]. Postharvest treatments of apple fruits are the only method remained to control SB and FS [17]. Different postharvest techniques such as apple dipped in chlorine were helpful in controlling SB and FS [18]. Sodium hypochlorite dips, chlorinated water and hydrogen peroxide were successfully used as postharvest treatments on apples in different areas of the world [17, 19-21]. These materials are already being used in apple cider processing thus they are considered safe for human use [17]. However, these postharvest treatments have not yet been tested on apples grown under climatic conditions of Rawalakot, Azad Jammu and Kashmir.

Therefore, the present study was designed to evaluate these postharvest treatments for the control of blemishes caused by SB and FS and also to investigate the influence of these treatments on the extension of shelf life of apple fruits during cold storage.

\section{Materials and methods Plant material}

Apple fruit samples (cv. Banky) were collected from a local orchard located at Rawalakot (altitude: $5374 \mathrm{ft}$, temperature range: -7 to $35^{\circ} \mathrm{C}$ ), District Poonch, Azad Jammu and Kashmir, Pakistan. Collected samples were shifted to the Post Graduate Laboratory, Department of Horticulture, Faculty of Agriculture, University of the Poonch, Rawalakot. Diseased free fruits were selected on the basis of visual appearance (uniform size, colour). Different disinfectants (sodium hypochlorite, copper sulphate, hydrogen peroxide and potassium bicarbonate) were used during the study. All the chemicals were purchased from Sigma Chemical Co. (St. Louis, MO).

\section{Preparation and application of chemical solutions}

Different concentrations of sodium hypochlorite (200, 500 and $800 \mathrm{ppm})$, copper sulphate (100, 200 and 300 ppm), hydrogen peroxide $(100,360$ and $480 \mathrm{ppm})$ and potassium bicarbonate (200, 500 and 800 ppm) solutions were prepared 30 minutes prior to use. Apple fruits were placed in jars containing above chemical solutions for 10 minutes and rotated continuously to ensure uniform exposure. In control treatment purified water was used instead of above mentioned disinfectants. After application of treatments, fruits were dried at room temperature for $24 \mathrm{~h}$ and then subsequently stored at $2^{\circ} \mathrm{C}$ for 90 days.

\section{Determination of physical quality Fruit blemishes}

Fruit blemishing was visually assessed at the end of storage and recorded at blemishes \%age.

\section{Fruit weight loss (\%)}


Fruit weight was measured with the help of electronic balance. Fruit was taken before treatments which serve as initial weight and the final weight was taken at the end of experiment after 90 days. Loss in weight was determined by using following formula:

$$
\text { Weight loss \%age }=\frac{\text { initial weight-final weight }}{\text { initial weight }} \times 100
$$

\section{Determination of chemical quality Total soluble solids (TSS)}

TSS was determined by using hand refractometer (Model: No. 507-I, ATAGO ${ }^{\circledR}$, Tokyo, Japan). Apple pulp (10 g) was ground by adding water $(40 \mathrm{ml})$ in a kitchen blender. Mixture was centrifuged at $5000 \mathrm{~g}$ for $5 \mathrm{~min}$. Filtrate from the mixture was separated using a filter paper. A drop from the filtrate was placed on the prism of refractometer to obtain value of TSS [22]. Refractometer was calibrated with purified water to give a $0 \%$ reading before analysis.

\section{Titratable acidity (\%)}

Titratable acidity was measured using the remaining filtrate of TSS. A $5 \mathrm{ml}$ aliquot was mixed with 2-3 drops of phenolphthalein and titrated with $0.1 \mathrm{~N} \mathrm{NaOH}$ until the colour changed to pink [22].

\section{Sugars (Reducing and Non-reducing sugars)}

Sugars were estimated from apple juice by the method described by Kulkarni et al. [23].

\section{Sensory evaluation}

Sensory evaluation for fruit colour, taste, flavour, texture and overall acceptability was done by a panel of eight trained members. Sensory behavior was scored according to the scoring method described by Maqbool et al. [22].

\section{Statistical analysis}

Experiments were arranged in a completely randomized design (CRD) with four replicates. Each replicate consisted of 15 fruits for each observation. Data was subjected to analysis of variance and tested for significant differences among treatments by the Duncan's multiple range test (DMRT) at $P<0.05$ using Statistical analysis system $\mathrm{SAS}^{\circledR}$.

\section{Results and discussion}

Physical quality changes in apple fruits Fruit blemishes

Reduction in fruit blemishes was observed in all the treatments of different surfactants (Table 1). However, the highest reduction was observed at 800 ppm sodium hypochlorite $(96 \%)$ which was comparable with the reduction of blemishes at $500 \mathrm{ppm}$ sodium hypochlorite (93\%). Similarly, reduction in blemishes was noticed at 300 ppm copper sulphate (93\%), 480 ppm hydrogen peroxide (93\%) and $800 \mathrm{ppm}$ potassium bicarbonate $(90 \%)$ which was nonsignificantly $(P>0.05)$ different with 200 ppm copper sulphate (90\%), 360 ppm hydrogen peroxide (92\%) and 500 ppm potassium bicarbonate $(89 \%)$, respectively. These results suggest that sodium hypochlorite had greater effect on apple fruit blemishes if applied as a postharvest treatment. This decrease in apple blemishes attributed to the fact that chlorine, which is the major active ingredient in sodium hypochlorite may interrupt the biological processes of the fungus which causes SB. It may inhibit the production of ATP's which is helpful in the respiratory electron transfer [24]. The effectiveness of buffered sodium hypochlorite against SB and FS was also reported by Batzer et al. [17].

On the basis of these results, 500 ppm sodium hypochlorite, $200 \mathrm{ppm}$ copper sulphate, 360 ppm hydrogen peroxide and 500 ppm potassium bicarbonate were selected to see 
their effects on apple fruits quality during cold storage.

Table 1. Effect of different surface disinfectants on reduction of fruit blemishes $(\%)$ in apple fruits stored at $2^{\circ} \mathrm{C}$ for 90 days $\left(^{\dagger}\right)$.

\begin{tabular}{|c|c|c|c|c|}
\hline Treatments & $\begin{array}{c}\text { Sodium } \\
\text { hypochlorite }\end{array}$ & $\begin{array}{c}\text { Copper } \\
\text { sulphate }\end{array}$ & $\begin{array}{c}\text { Hydrogen } \\
\text { peroxide }\end{array}$ & $\begin{array}{c}\text { Potassium } \\
\text { bicarbonate }\end{array}$ \\
\hline $\mathrm{T}_{1}$ & $0.00 \mathrm{c}$ & $0.00 \mathrm{c}$ & $0.00 \mathrm{c}$ & $0.00 \mathrm{c}$ \\
\hline $\mathrm{T}_{2}$ & $82.67 \mathrm{~b}$ & $85.33 \mathrm{~b}$ & $80.30 \mathrm{~b}$ & $84.60 \mathrm{~b}$ \\
\hline $\mathrm{T}_{3}$ & $92.66 \mathrm{a}$ & $90.00 \mathrm{ab}$ & $92.40 \mathrm{a}$ & $88.60 \mathrm{ab}$ \\
\hline $\mathrm{T}_{4}$ & $95.66 \mathrm{a}$ & $93.66 \mathrm{a}$ & $93.00 \mathrm{a}$ & $90.20 \mathrm{a}$ \\
\hline
\end{tabular}

* Means with different letters in column are significantly different at $P<0.05$ using DMR test. Whereas, $\mathrm{T}_{1}$, Control; solutions of sodium hypochlorite $\left(T_{2}=200, T_{3}=500\right.$ and $\left.T_{4}=800 \mathrm{ppm}\right)$, for solutions of copper sulphate $\left(\mathrm{T}_{2}=100\right.$, $\mathrm{T}_{3}=200$ and $\left.\mathrm{T}_{4}=300 \mathrm{ppm}\right)$, for solutions of hydrogen peroxide $\left(\mathrm{T}_{2}=100, \mathrm{~T}_{3}=360\right.$ and $\left.\mathrm{T}_{4}=480 \mathrm{ppm}\right)$ and for solutions of potassium bicarbonate $\left(\mathrm{T}_{2}=200, \mathrm{~T}_{3}=500\right.$ and $\left.\mathrm{T}_{4}=800 \mathrm{ppm}\right)$

\section{Fruit weight loss (\%)}

The highest weight loss was observed in control fruits (approx. 85\%), while the least weight loss (approx. 30\%) was recorded in fruits dipped in 500 ppm sodium hypochlorite which was non-significantly different $(P<0.05)$ with 360 ppm hydrogen peroxide (Figure 1). This vapor pressure difference among the surrounding environment and the produce of fresh fruit and vegetables is the basic principle of weight loss [25]. In our results, retention of vapor pressure and reduction in weight loss might be due to the reduced attack of disease on the surface disinfectant treated fruit. In control fruits the production of pectolytic enzymes by the microorganisms of SB might increase the metabolic rate of fruits and results in maximum weight loss.

\section{Chemical quality changes in apple fruits Total soluble solids (TSS)}

A significant $(P<0.05)$ difference in TSS was observed among fruits treated with different disinfectants and untreated control (Figure 2). The lowest value of TSS was observed in control fruits where no treatment was applied. While the highest value of TSS was recorded in fruits treated with $500 \mathrm{ppm}$ sodium hypochlorite which was followed by 360 ppm hydrogen peroxide, 500 ppm potassium bicarbonate and 200 ppm copper sulphate. Generally TSS increases during storage. TSS concentration is up regulated during the ripening process and down regulated in the ripe fruits [24]. Decrease in TSS in control fruits may be due to high water loss caused by the enzymatic activities of SB and FS complex and leads to the solubilization of the polyuronides and hemicelluloses in mature fruits [26].

\section{Titratable acidity (\%)}

A significant $(P<0.05)$ difference in titratable acidity was observed among fruits treated with different disinfectants and untreated control (Figure 3). The highest value of titratable acidity was observed in control fruits where no treatment was applied. While the lowest value of titratable acidity was recorded in fruits treated with 500 ppm sodium hypochlorite which was followed by 360 ppm hydrogen peroxide, 500 ppm potassium bicarbonate and 200 ppm copper sulphate. This decrease in titratable acidity in treated fruits might be due to the open matrix of surface disinfectants which increased the water loss and resulted in the reduction of titratable acidity concentration in treated apple fruits.

\section{Sugars (mg 100g-1)}

A significant $(P<0.05)$ difference in reducing and non-reducing sugars was observed in fruits treated with different disinfectants and control fruits (Figure $4 \mathrm{a}$ and $4 \mathrm{~b}$ ). The lowest value in reducing and non-reducing sugars was recorded in control fruits while the highest value was recorded in fruits treated 
with 500 ppm sodium hypochlorite followed by 200 ppm copper sulphate and 360 ppm hydrogen peroxide. Starch content of fruit turned into sugars during the storage. But in case of control fruits this minimum value of sugars indicates that after ripening the fruits used stored sugars for its respiration [27]. Decrease in non-reducing sugars in control fruits is due to the fact that some of the nonreducing sugars were converted into the reducing sugars with enzymatic conversions [23].

\section{Sensory evaluation}

Sensory evaluation of disinfectant treated and untreated fruits at the end of storage period revealed significant $(P<0.05)$ differences in taste, flavour, texture and overall acceptability (Table 2). Control fruits were shrivelled and turned yellow in colour and achieved the lowest scores from panellists. Whereas, fruits treated with 500 ppm sodium hydroxide attained the highest scores in all evaluation parameters. The highest overall acceptability of fruits treated with $500 \mathrm{ppm}$ sodium hypochlorite could be due to their shiny skin colour, better taste, flavour and texture. Retention of taste, colour and flavour in fruits treated with $500 \mathrm{ppm}$ sodium hypochlorite might be due to the less water loss which helped in inhibiting the respiration rate of apples for up to 90 days. Shrivelling in control fruits may be due to the loss of water content or due to higher metabolic activities. Fungal complex of SB might cause cell wall degradation which is an important rationale for shrivelling of control fruits.

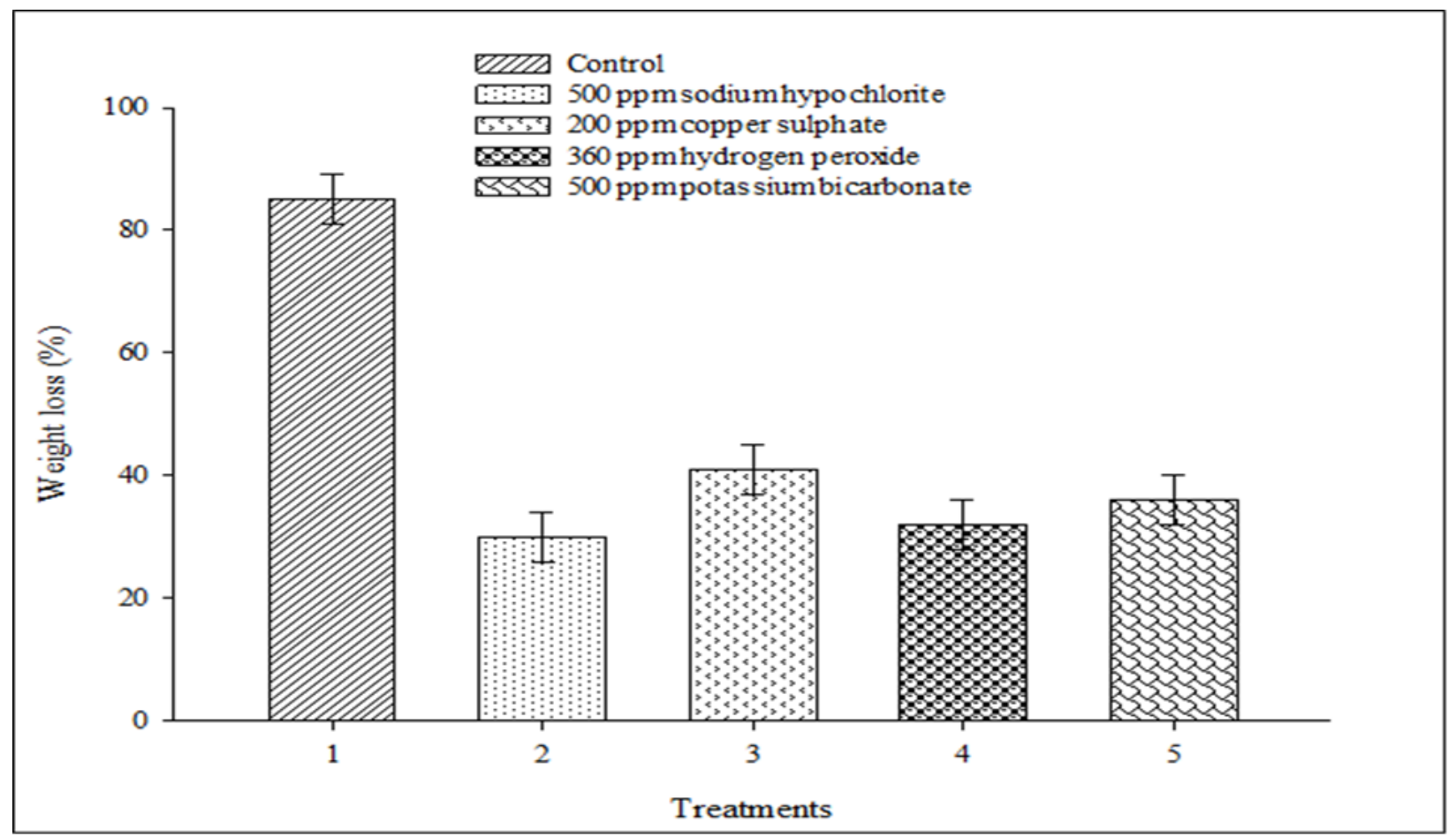

Figure 1. Effect of different surface disinfectants on reduction of weight loss (\%) in apple fruits stored at $2^{\circ} \mathrm{C}$ for 90 days. Vertical bars represent the standard error of means for four replicates 


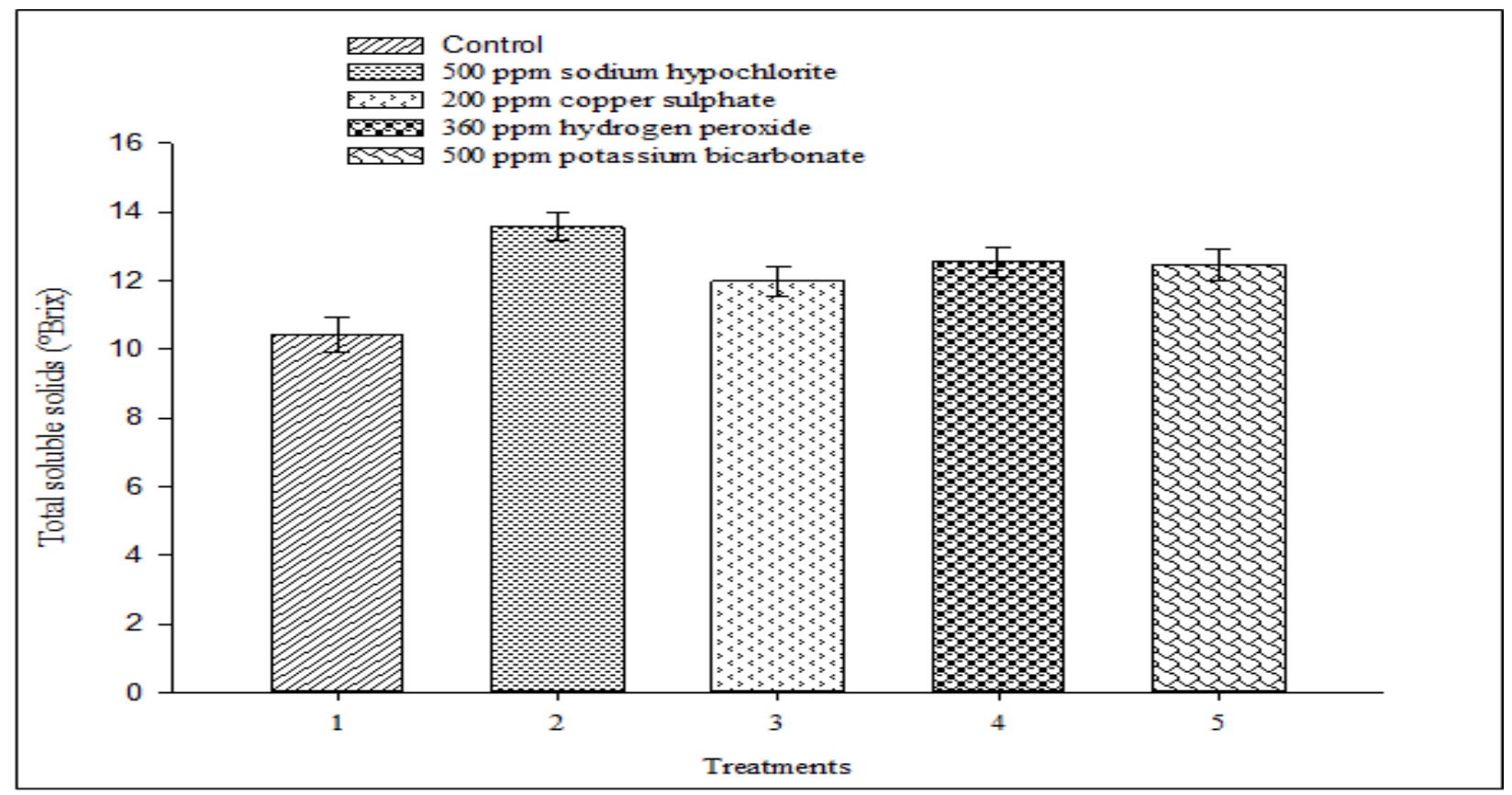

Figure 2. Effect of different surface disinfectants on total soluble solids ( ${ }^{\circ}$ Brix) in apple fruits stored at $2^{\circ} \mathrm{C}$ for 90 days. Vertical bars represent the standard error of means for four replicates.

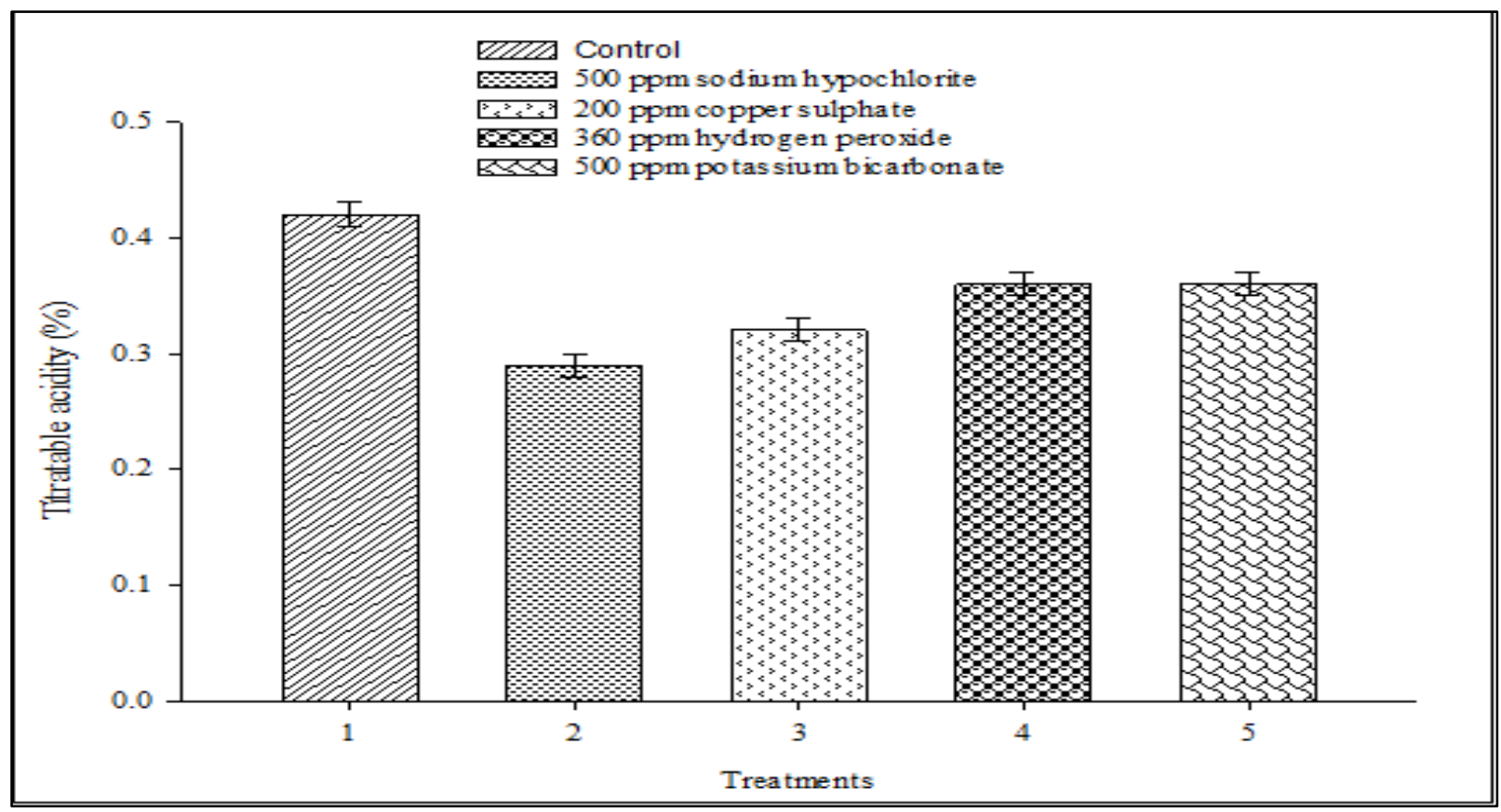

Figure 3. Effect of different surface disinfectants on titratable acidity (\%) in apple fruits stored at $2^{\circ} \mathrm{C}$ for 90 days. Vertical bars represent the standard error of means for four replicates. 


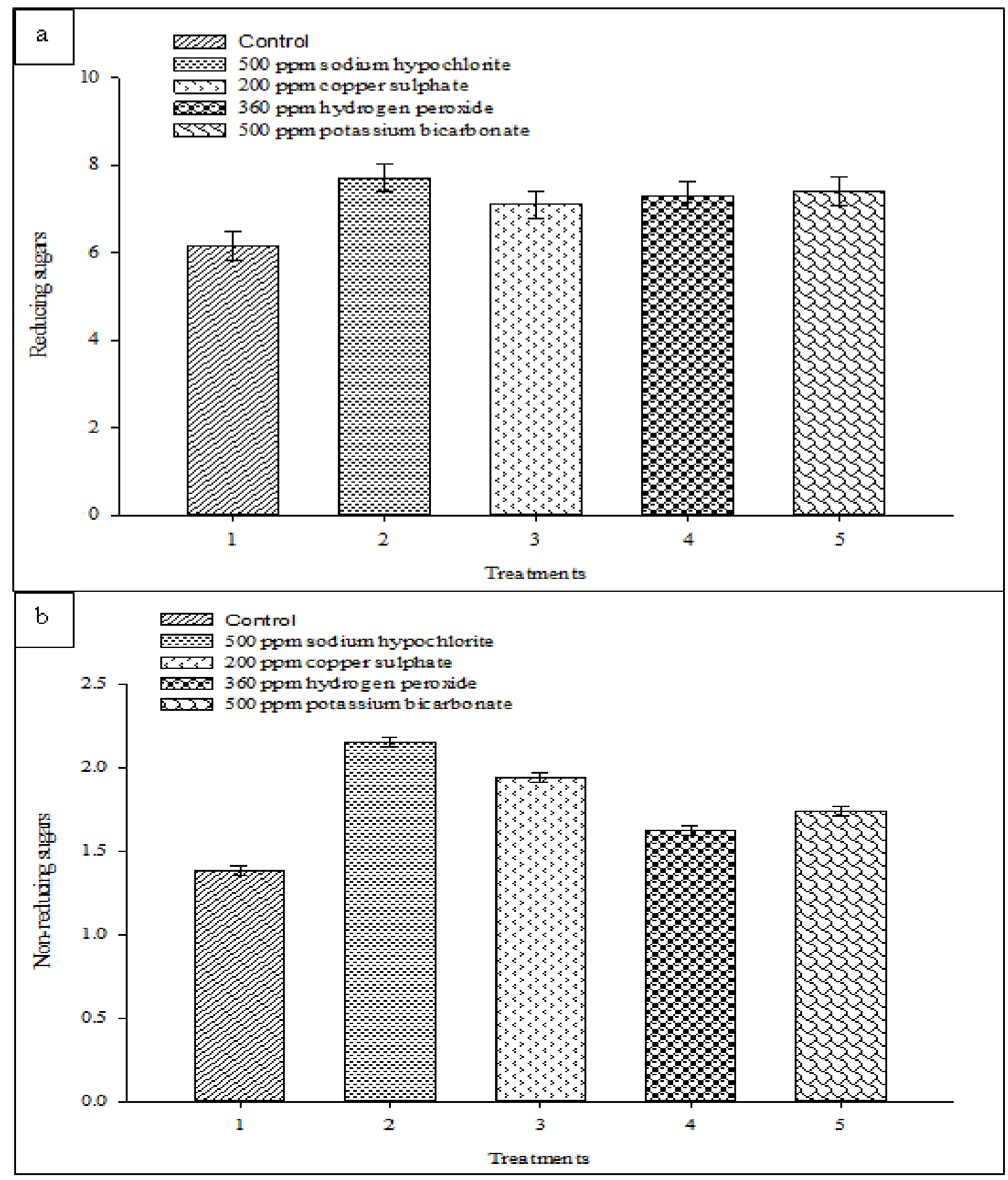

Figure 4. Effect of different surface disinfectants on (a) reducing sugars (b) non-reducing sugars $\left(\mathrm{mg}^{\left.100 \mathrm{~g}^{-1}\right)}\right.$ in apple fruits stored at $2^{\circ} \mathrm{C}$ for 90 days. Vertical bars represent the standard error of means for four replicates 
Table 2. Effect of different surface disinfectants on sensory evaluation of apple fruits stored at $2^{\circ} \mathrm{C}$ for 90 days $\left(^{\dagger}\right)$.

\begin{tabular}{|c|c|c|c|c|}
\hline Treatments & Taste & Flavour & Texture & $\begin{array}{c}\text { Overall } \\
\text { acceptability }\end{array}$ \\
\hline Control & $2.5 \mathrm{~d}$ & $2.3 \mathrm{~d}$ & $3.1 \mathrm{~d}$ & $2.0 \mathrm{~d}$ \\
\hline 500 ppm sodium hypochlorite & $7.5 \mathrm{a}$ & $6.5 \mathrm{a}$ & $6.7 \mathrm{a}$ & $7.0 \mathrm{a}$ \\
\hline 200 ppm copper sulphate & $5.5 \mathrm{bc}$ & $5.2 \mathrm{c}$ & $5.2 \mathrm{c}$ & $5.1 \mathrm{c}$ \\
\hline 360 ppm hydrogen peroxide & $6.0 \mathrm{~b}$ & $6.0 \mathrm{~b}$ & $5.5 \mathrm{~b}$ & $5.5 \mathrm{~b}$ \\
\hline 500 ppm potassium bicarbonate & $5.5 \mathrm{bc}$ & $5.5 \mathrm{bc}$ & $5.0 \mathrm{c}$ & $5.0 \mathrm{c}$ \\
\hline
\end{tabular}

${ }^{*}$ Means with different letters in column are significantly different at $P<0.05$ using DMR test

\section{Conclusion and recommendations}

In conclusion, present study indicates that dipping of fruits in $500 \mathrm{ppm}$ sodium hypochlorite could be helpful in maintaining apple quality for up to 90 days. Thus, it could be used by apple growers to reduce SB and FS blemishes from fruits and enhance physicochemical quality of apple fruits.

\section{Authors' contributions}

Conceived and designed the experiments: MJ Ahmed \& SZA Shah, Performed the experiments: K Fareed, Analyzed the data: K Fareed \& N Zahid, Contributed materials/ analysis/tools: SZA Shah \& A Hamid, Wrote the paper: M Maqbool \& MJ Ahmed.

\section{Acknowledgements}

Authors are grateful to the local fruit growers for providing apple fruits free of cost for this research study.

\section{References}

1. Shakir I, Durrani Y, Hussain I, Qazi IM \& Zeb A (2008). Physicochemical analysis of apple and pear mixed fruit jam prepared from varieties grown in Azad Jammu and Kashmir. Pak J Nutrition 7: 177-180.

2. Draz IS, El-Gremi SM \& Youssef WAE (2016) Pathogens associated with wheat black-point disease and responsibility in pathogenesis. J Environ Agric Sci 8: 7178.

3. Islam W \& Awais M (2017) Selection of rice genotypes through comparative response to bacterial leaf blight disease caused by Xanthomonas oryzaepv. oryzae. J Environ Agric Sci 11: 9-14.

4. Salim HA, Simon S \& Lal AA (2017) Integrated diseases management (IDM) against tomato (Lycopersicon esculentum L.) Fusarium wilt. J Environ Agric Sci 11: 29-34.

5. Shehzad I, Maqbool M, Zahid N, Shah SZA, Ahmed MJ, Hamid A, Yaqoob A \& Shehzad MA (2018) Effect of organic fungicides on sooty blotch, flyspeck and quality of apple cv. Banki grown in Rawalakot, Azad Jammu and Kashmir. Pure Appl Biol 7: 400-406.

6. Ismail SI, Batzer JC, Harrington TC, Crous PW, Li H \& Gleason ML (2016) Ancestral state reconstruction infers phytopathogenic origins of sooty blotch and flyspeck fungi on apple. Mycologia 108: 292-302.

7. Miñarro $\mathrm{M}$, Blázquez $\mathrm{MD}$, MuñozSerrano A \& Dapena E (2013) Susceptibility of cider apple cultivars to the sooty blotch and flyspeck complex in Spain. European J Plant Pathol 135: 201209.

8. Ismail SI, Batzer JC, Harrington TC \& Gleason ML (2014) Phenology of infection on apple fruit by sooty blotch and flyspeck species in Iowa apple orchards. Plant Dis 100: 352-359.

9. Batzer JC, Weber RWS, Mayfield DA \& Gleason ML (2016) Diversity of sooty blotch and flyspeck complex on apple in Germany. Mycol Progr 15: 2.

10. Weber RWS, Späth S, Buchleither S \& Mayr U (2016) A review of sooty blotch and flyspeck disease in German organic apple production. Erwerbs-Obstbau 58: 63-79.

11. Brown EM \& Sutton TB (1993) Control of sooty blotch and flyspeck of apple with 
Captan, Mancozeb, and Mancozeb combined with Dinocap in dilute and concentrate applications. Plant Dis 70: 281-284.

12. Batzer JC, Stensvand A, Mayfield DA \& Gleason ML (2015) Composition of the sooty blotch and flyspeck complex on apple in Norway is influenced by location and management practices. European $J$ Plant Pathol 141: 361-374.

13. Asif A, Raza MH, Azam MK \& Manzoor H (2004) Effect of different periods of ambient storage on chemical composition of apple fruit. Int J Agric Biol 6: 568-571.

14. Kayani FA, Zahid N, Maqbool M, Ahmed MJ, Hamid A, Shah SZA \& Yaqoob A (2018) Effect of climatic factors on sooty blotch, flyspeck intensity and fruit quality of apple (Malus domestica Borkh.). Pure Appl Biol 72: 727-735.

15. Fareed K (2012) Effect of surface disinfectants on sooty blotch, fly speck and quality of apple. Master's Thesis, University of Azad Jammu \& Kashmir.

16. Belding RD, Blankenship SM, Young E \& Leidy RB (1998) Composition and variability of epicuticular waxes in apple cultivars. J Amer Soc Hortic Sci 123: 348356.

17. Batzer JC, Gleason ML, Weldon B, Dixon PM \& Nutter FW Jr (2002) Evaluation of postharvest removal of sooty blotch and flyspeck on apples using sodium hypochlorite, hydrogen peroxide with peroxyacetic acid, and soap. Plant Dis 86: 1325-1332.

18. Floyd F \& Hendrix JR (1991) Removal of sooty blotch and flyspeck from apple fruit with chlorine dip. Plant Dis 75: 742-743.

19. Colby AS (1920) Sooty blotch of pomaceous fruits. Trans III Acad Sci 13: 139-179.

20. Sapers GM \& Simons GF (1998) Hydrogen peroxide disinfection of minimally processed fruits and vegetables. Food Technol 52: 48-52.

21. Winsiewsky MA, Glatz BA, Gleason ML \& Reitmeier CA (2000) Reduction of Escherichia coli O157:H7 counts on whole fresh apples by treatment with sanitizers. J Food Protec 63: 703-708.

22. Maqbool M, Ali A, Alderson PG, Zahid N \& Siddiqui Y (2011) Effect of a novel edible composite coating based on gum arabic and chitosan on biochemical and physiological responses of banana fruits during cold storage. J Agric Food Chem 59: 5474-5482.

23. Kulkarni SG, Kudachikar VB \& Prakash MNK (2011) Studies on physico-chemical changes during artificial ripening of banana (Musa sp) variety 'Robusta'. J Food Sci Technol 48: 730-734.

24. Ali A, Chow WL, Zahid N \& Ong MK (2014) Efficacy of propolis and cinnamon oil coating in controlling post-harvest anthracnose and quality of chilli (Capsicum annum L.) during cold storage. Food Bioprocess Technol 7: 2747-2748.

25. Yaman O \& Bayoindirli L (2002) Effects of an edible coating and cold storage on shelf-life and quality of cherries. Lebensmittel-Wissenschaft Technol 35: 146-150.

26. Hernández-Muñoz P, Almenar E, Del Valle V, Velez D \& Gavara R (2008) Effect of chitosan coating combined with postharvest calcium treatment on strawberry (Fragaria $x$ ananassa) quality during refrigerated storage. Food Chem 110: 428-435.

27. Ali A, Mahmud TMM, Kamaruzaman S \& Siddiqui Y (2011) Effect of chitosan coatings on the physico-chemical characteristics of Eksotika II papaya (Carica papaya L.) fruit during cold storage. Food Chem 124: 620-626. 